\title{
An Examination of the Domain of Multivariable Functions Using the Pirie-Kieren Model
}

\author{
Sare Sengul ${ }^{1}$, Sevda Goktepe Yildiz ${ }^{2, *}$ \\ ${ }^{1}$ Ataturk Faculty of Education, Marmara University, Goztepe Campus, Turkey \\ ${ }^{2}$ Faculty of Education, Yildiz Technical University, Davutpasa Campus, Turkey
}

Copyright $\mathrm{C} 2016$ by authors, all rights reserved. Authors agree that this article remains permanently open access under the terms of the Creative Commons Attribution License 4.0 International License

\begin{abstract}
The aim of this study is to employ the Pirie-Kieren model so as to examine the understandings relating to the domain of multivariable functions held by primary school mathematics preservice teachers. The data obtained was categorized according to Pirie-Kieren model and demonstrated visually in tables and bar charts. The study group consisted of forty sophomore primary school mathematics preservice teachers during the process of their education at a state university in Turkey. The data were collected via a test consisting of open-ended questions prepared by the researchers of the study. The findings demonstrated that preservice teachers submitted answers predominantly at the "property noticing" stage as defined by the Pirie-Kieren model. In addition, answers by participants were also encountered within the "image making" and "image having" stages of the model.
\end{abstract}

Keywords Multivariable Functions, Finding Domain of a Function, The Pirie-Kieren Model

\section{Introduction}

The concept of understanding is employed frequently in mathematics education; however researchers have worked for many years to create a clear definition of the term "understanding". According to Skemp [1], this concept encompasses two different meanings: relational understanding and instrumental understanding. At a later point in time, Skemp [2] defined two further categories. Through such a process, four categories were created for the concept of understanding; these were designated as: relational, instrumental, logical, and symbolic understanding [3].

On examination of the descriptions, definitions, and categorizations created to date, it may be observed that researchers hold different points of view with respect to the concept of understanding. Studies conducted over recent years have focused in particular on the Pirie and Kieren's Growth of Mathematical Understanding Model and
Dubinsky's APOS theory [4]. This study focuses on Pirie and Kieren's Growth of Mathematical Understanding Model.

\subsection{Pirie-Kieren Theory}

Pirie and Kieren initially created a definition of mathematical understanding by developing Von Glaserfeld's definition of understanding. Von Glasersfeld [5] stated that the organization of the people and individuals and their construction of knowledge needed to take place within a process of understanding. By employing and organizing the key elements of this term and developing it for the circumstances of their field, they developed their own theoretical positions with regard to the understanding of mathematics [4].

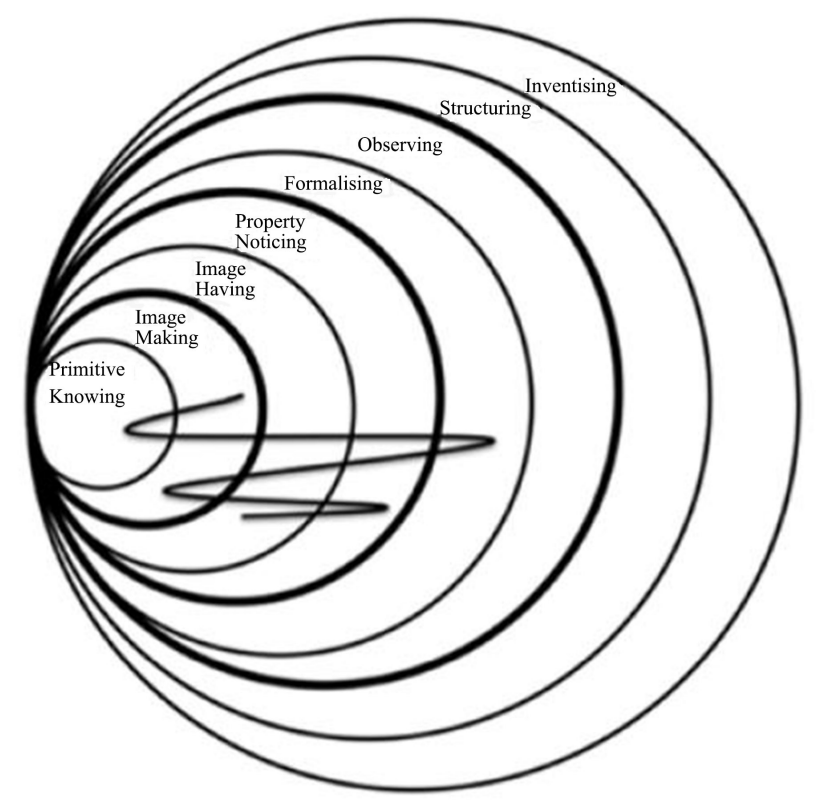

Figure 1. Growth of Mathematical Understanding Model (Pirie \& Kieren, 1994)

Pirie and Kieren's Growth of Mathematical Understanding Model consists of eight interwoven layers or 
stages. These layers are labelled as primitive knowing, image making, image having, property noticing, formalising, observing, structuring, and inventising [6].

The first layer of understanding is that of primitive knowing. Primitive knowing constitutes the foundation of mathematical understanding and is necessary in order to understand certain special concepts. Primitive knowing is not necessarily a low level of mathematics, but rather the starting point so as to be able to understand any area of mathematics [6]. Therefore, learners must possess the required prior information or knowledge so as to make sense of mathematical concepts.

The second layer of understanding is that of image making. At this stage, the student is asked to make a distinction between his or her preliminary or previous knowledge and the application of knowledge within the context of new methods [6]. The learner involves himself with activities so as to acquire idea(s) with respect to the concepts that he has been introduced to [7]. For example in a study conducted by Argat [3], students used materials distributed to them in order to define probable situations. As two students worked together and created an activity, the students could be said to be at the "image making" stage according to Pirie and Kieren's theory.

The third layer or stage is that of "image having". A person at the "image having" level can create a mental construct to solve a problem without carrying out specific activities [6]. For example, students are able to easily solve questions without having to resort to using tangible materials [3].

The fourth layer of understanding is described as the "property noticing" stage in which the person is able to combine the images he holds [6]. For example, the students, by examining their mental images are able to notice the mathematical relationship between "and" and "or" logical connectives [3].

The fifth layer of understanding is that of "formalising", in which the learner employs mathematical expressions so as to be able to create a general expression [6]. Furthermore, the learner is able to create a mathematical description and develop formulae and algorithms for this purpose [8].

In the sixth stage or layer, known as "observing" the learner, who has become able to formalise or to express his thoughts abstractly, simultaneously coordinates a formal activity and through this coordination process becomes able to express his ideas or thoughts in the form of a theory [6].

The seventh layer that continues on from the above process is known as the "structuring stage". In the structuring stage, the students create a model by combining their observations [8]. They are able to account for their formal observations in a logical manner, and prove their findings using expressions that resemble theorems [9].

In the final stage or layer known as "inventising", the learner reaches a completely structured understanding and is able to formulate new questions from which a totally new concept may emerge [6].

The development of understanding is not a one-way process. The layers of the model are intertwined and every layer or stage includes the layer that follows it and each of the layers that have preceded it. The development of understanding is a dynamic process that flows in both a forward and backward direction between the layers of the learning process [6].

\subsection{Multivariable Functions}

A function from $A$ to $B$ is expressed in the following form: $f: A \rightarrow B$. Set $A$ is here defined as the domain of the set, while set $B$ is defined as the range of the set. An $f$ function from $A$ to $B$, may be described as a mathematical rule in which every single element in $A$ is equal to one and only one single element in $B$. For example, in a function written as $f: x \rightarrow 2 x$ consisting of real numbers to real numbers the element $x$, that represents an undefined real number is denoted as the variable. Functions are generally expressed as follows: $y=f(x)$. Here, the $x$ element is denoted as an independent variable, while $y$ is defined as a dependent variable [10]. Functions that contain single independent variables are known as single variable functions while those that include more than one variable are labelled as multivariable functions.

A function of two variables are expressed in the following manner: $z=f(x, y)$. Should the function in the set of real numbers be defined, the function can be shown in such a case as: $f: R^{2} \rightarrow R$. It follows that the domain of the function can be shown as an area on the $x-y$ coordinate plane. In functions involving three variables, the domain represents an offset from the surface of the $x-y-z$ coordinate place.

Independent variables are found in numerous events that we encounter in our daily lives. For instance, we calculate the volume of objects with a rectangular prism shape using the following formula. Furthermore, the field of application of multi-variable functions is very extensive compared to that of single variable functions. Multivariable functions that incorporate such a wide field of application form the basis of many fields of mathematics such as Analysis I-II, Functional Analysis, Vectoral Analysis, Differential Geometry and Applied Geometry [11].

\subsection{Significance of the Study}

The finding of the domain of single variable functions and the finding of domain of multivariable functions may be said to form the primitive knowing stage according to the Pirie-Kieren model. A great level of reasoning is necessary to identify the situation in which more than one variable is present in multivariable functions and to think of the function that should be given holistically. From this perspective, an examination of this situation is carried out in this study employing the Pirie-Kieren model.

Academic literature exists containing studies carried out on the topic of the understanding of preservice teachers ([8], [12]) and teachers ([13], [14]) related to Pirie-Kieren Model. It should be mentioned that there has been an increase in 
research studies in mathematics education focusing on the Pirie-Kieren model (e.g., [3], [15], [16]) There is also a larger number of studies available concerned with students' general understanding and misunderstanding of concepts with regard to the concept of functions, (e.g., [17], [18], [19], [20]). The researchers also encountered studies concerning the limit concept with regard to functions with two variables (e.g., [11], [21]). Researchers also encountered research concerned with the finding of the domain and the designation of coordinate planes in multivariable functions. For this reason, it is felt that this study will serve to address an issue in the field that is in need of attention.

\subsection{Purpose of the Study}

The main aim of this study is to investigate the understandings of mathematics preservice teachers with regard to the domain of multivariable functions using the Pirie-Kieren model in a small group of students. The layers which the preservice teachers' responses in were identified. Thus, the participants' understandings were examined through a new perspective. There was an attempt to find an answer to the following research question:

"On which layers of the Pirie-Kieren Model are the understandings of primary school mathematics preservice teachers placed concerning the domain of multivariable functions?

\section{Method}

This study that examined the understanding of primary school mathematics preservice teachers regarding the domain of multivariable functions was a descriptive study. The data obtained was summarized according to previously-defined dimensions and interpreted. Preservice teachers' responses for each question were placed in Pirie-Kieren layers which were formed previously by the researchers. A coding scheme was created according to Pirie-Kieren model proposed by Pirie and Kieren [6]. All coded student answers were presented numerically in tables and bar charts. Similar analysis method was used in some mathematics education research (e.g., [22], [23], [24]). Students' answers were categorized according to Pirie-Kieren model in the understanding of some mathematical concepts such as infinite numerical series [25], geometric transformations [15] in other research. Besides, example student answers for each question were illustrated according to Pirie-Kieren layers (Image Making, Image Having, Property Noticing) in the present study. Finally, four students' answers were given in the mathematical understanding scheme.

\subsection{Study Group}

The working group of the study consisted of 40 sophomore preservice teachers studying on the primary mathematics teaching program at a state university. All of the students who participated in the study had completed the Analysis II course. Such learning objectives as finding the domain of multivariable functions and drawing of the related graphs are included in the Primary School Mathematics Teaching Curriculum. Furthermore, topics such as limits in multivariable functions, derivatives, and calculating integrals are also present. The students possess sufficient knowledge, on account of completing this course, to be able to answer questions that arise within the context of this research study.

\subsection{Data Collection Tool}

In this study, an achievement test consisting of open-ended questions prepared by the researchers was used during the data collection stage. In the question preparation stage, the opinions of two experts in mathematical education were elicited. Four questions were included in the test. On account of the fact that every question was to be examined and answered in detail by the participants, it was felt that the number of questions was adequate. The questions were in particular connected to the finding of domain sets and demonstration of coordinate planes in multivariable functions. Functions with both two and three variables were included within the questions. The preservice teachers, on account of having seen these concepts during the Analysis II course, possessed sufficient knowledge to be able to submit answers concerning the concepts that they faced.

The questions that were used during data collection are as seen below:

1. Find the domain of $f(x, y)=\sqrt{y \cdot \sin x}$ and show this on the coordinate plane.

2. Find the domain of $f(x, y)=\frac{1}{\sqrt{y-\sqrt{x}}}$ and show this on the coordinate plane.

3. Find the domain of $f(x, y)=\arctan \frac{x}{y}$ and show this on the coordinate plane.

4. Find the domain of $f(x, y, z)=\ln \left(4-x^{2}-y^{2}-\right.$ $z^{2}$ ) and show this on the coordinate plane.

\subsection{Analysis of the Data}

The obtained data was analyzed according to Pirie-Kieren model. A coding procedure was created depending on the growth of mathematical understandings of preservice teachers and the concept of the domain of multivariable functions. The Pirie-Kieren Model that is used to explain in particular the growth of the individual understandings contains eight action stages. These stages are designated as primitive knowing, image making, image having, property noticing, formalizing, observing, structuring, and inventising. In the data analysis stage, it was determined at which level the responses of the preservice teachers fitted this model. In this stage, two different encoded responses were placed at appropriate stages in the model. When the researchers had placed an answer at different levels, a detailed discussion and debate 
then took place as to which would be the most suitable level; a consensus of opinion was then reached and the answer was placed at the appropriate level. Having created different headings for the four questions, the answers that had been placed according to the available Pirie-Kieren levels were then presented. At this stage, researchers made use of bar charts. Furthermore, so as to make the levels clear, examples were given from answers provided by students.

The topic of the research, namely the finding of domain of multivariable functions and their display on the coordinate plane was then defined. This topic, when examined in light of the Pirie-Kieren model, it was seen as appropriate to create the following descriptions for each stage.

Primitive knowing stage: As a basis, the understanding of the concept of a function is reached as a learning objective. In single variable functions, the domain may found and displayed on a Cartesian plane.

The image making stage: The student becomes aware of the issue of finding a domain plane in multivariable functions.

The image having stage: The student is involved in mental activities involving the question given.

The property noticing stage: The student researches the characteristics of the image that he possesses, and defines connections and points of difference. For example, he explains consciously which elements must be included in a domain set.

The formalising stage: The student is able to define domain sets for all functions in general without thinking of a specific question.

The observation stage: The student at this stage can now reflect on what he had learned and the coordination of theorems with one another.

The structuring stage: The student is able to express his previous experiences mathematically in the form of a new theory.

The inventising stage: The student, by extending the mental constructs he previously had formulated, reaches a new level of understanding and is able to create new questions. Through this process, he is able to find the domain of multivariable functions and produce questions related to these and provide explanations.

The student may not be able to find appropriate answers at every stage with regard to the finding of domain of multivariable functions and their demonstration on the coordinate plane. For the purposes of this study, and with respect to the data obtained, the students' answers were placed according to the appropriate stages of the model.

Furthermore, the answers of the four students selected from the perspective of the visualization of the transitions between the layers of the model, were then rendered clearly visible upon the model itself. In making selections, those students who had made transitions between the different layers of the model were chosen for special consideration.

\section{Findings}

\subsection{Findings with Regard to the First Question}

The answers of primary mathematics preservice teachers to the question "Find the domain of $f(x, y)=$ $\sqrt{y \cdot \sin x}$ and show this on the coordinate plane" were evaluated according to the Pirie-Kieren model and the following findings were obtained.

Table 1. Pirie-Kieren Understanding Levels for the First Question

\begin{tabular}{cccc}
\hline & $\begin{array}{c}\text { Image } \\
\text { making }\end{array}$ & $\begin{array}{c}\text { Image } \\
\text { having }\end{array}$ & $\begin{array}{c}\text { Property } \\
\text { noticing }\end{array}$ \\
\hline $\mathbf{1}^{\text {st }}$ Question & - & 3 & 37 \\
\hline
\end{tabular}

From the 40 answers submitted by students to the first question, 37 were placed in the "Property Noticing" stage while three answers were included in the "Image Having" stage. The situation related to the breakdown of the answers is highlighted on the bar chart below.

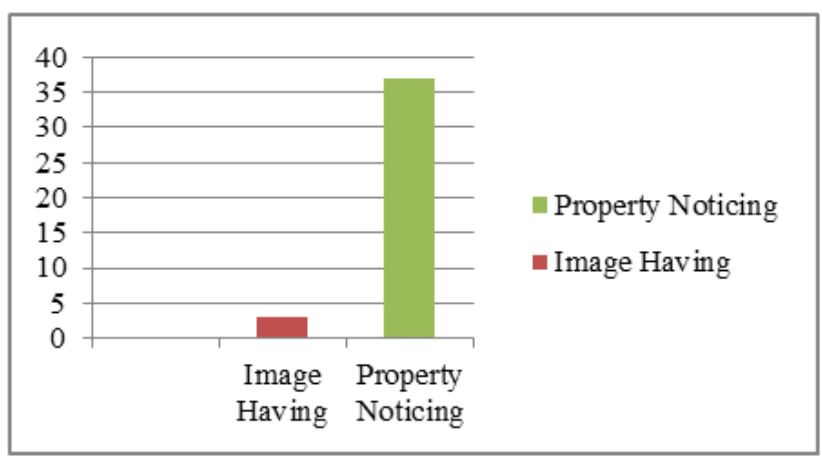

Figure 2. Bar chart for the first question

Examples of answers of students included in the "Image Having" and "Property Noticing" stages are presented below.

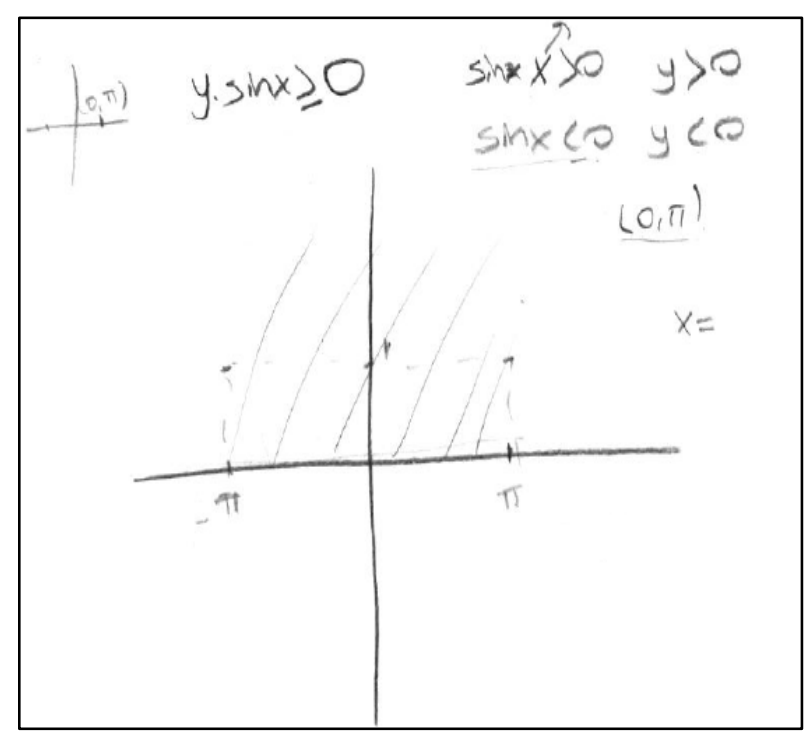

Figure 3. An example student answer included in the "Image Having" stage 

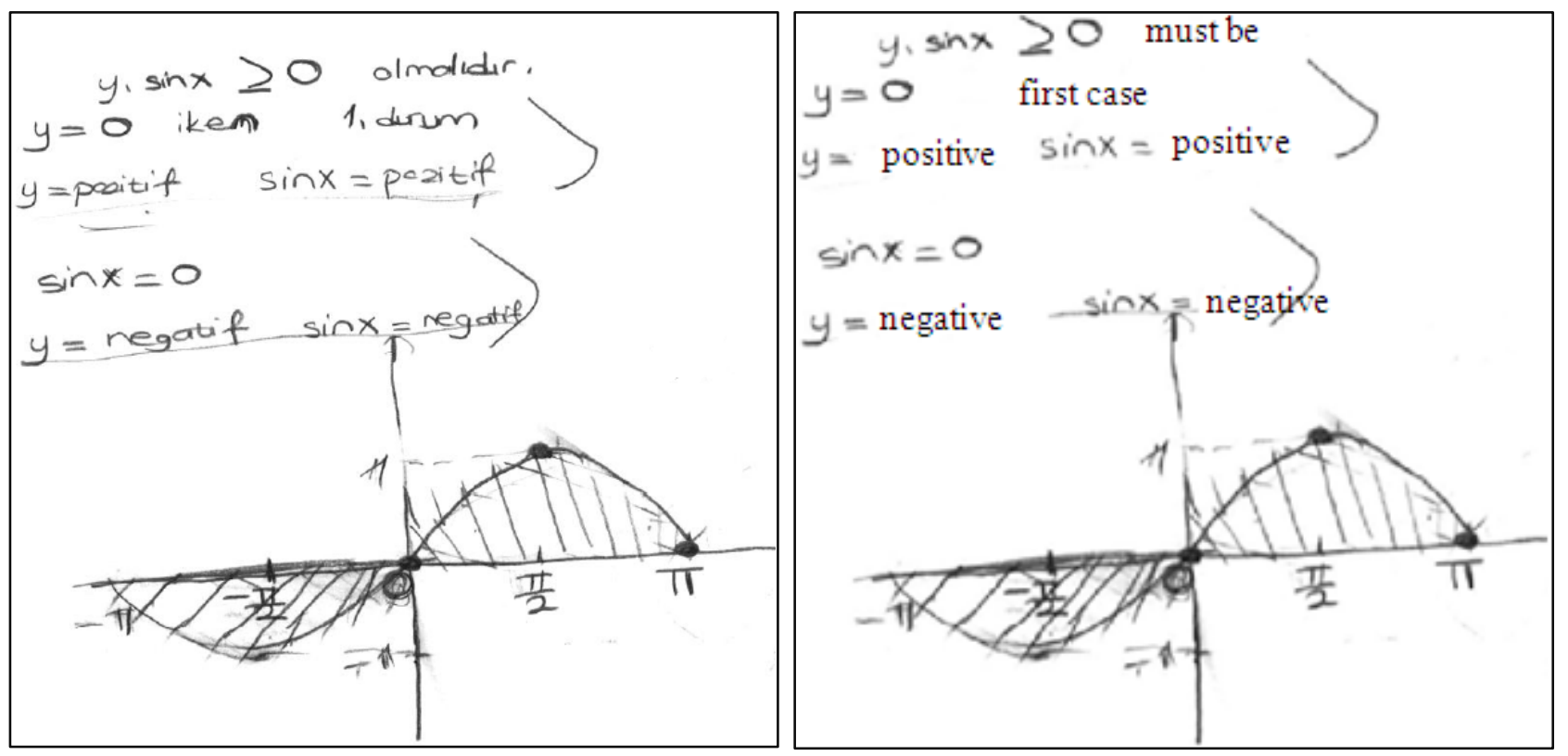

Figure 4. An example student answer included in the "Property Noticing" stage

\subsection{Findings with regard to the Second Question}

The answers that teacher candidates gave to the question "Find the domain of $f(x, y)=\frac{1}{\sqrt{y-\sqrt{x}}}$ and show this on the coordinate plane" were evaluated according to the Pirie-Kieren model and the findings shown below were obtained.

Table 2. Pirie-Kieren Understanding Levels for the Second Question

\begin{tabular}{cccc}
\hline & $\begin{array}{c}\text { Image } \\
\text { making }\end{array}$ & $\begin{array}{c}\text { Image } \\
\text { having }\end{array}$ & $\begin{array}{c}\text { Property } \\
\text { Noticing }\end{array}$ \\
\hline $\begin{array}{c}\mathbf{2}^{\text {nd }} \\
\text { Question }\end{array}$ & - & 8 & 32 \\
\hline
\end{tabular}

From the answers submitted by 40 students to the first question, 32 were included in the "property noticing" stage, while 8 were included in the "Image Having" stage. The situation regarding the breakdown of the answers is shown in the bar graph below.

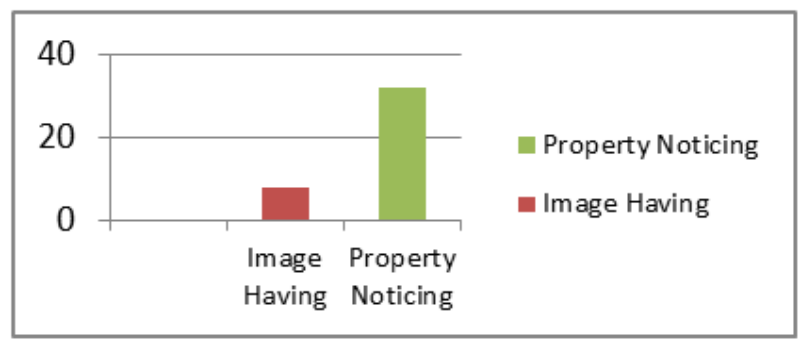

Figure 5. Bar chart for the second question

Example answers for student answers that were included within the "Image Having" and "Property Noticing" stages.

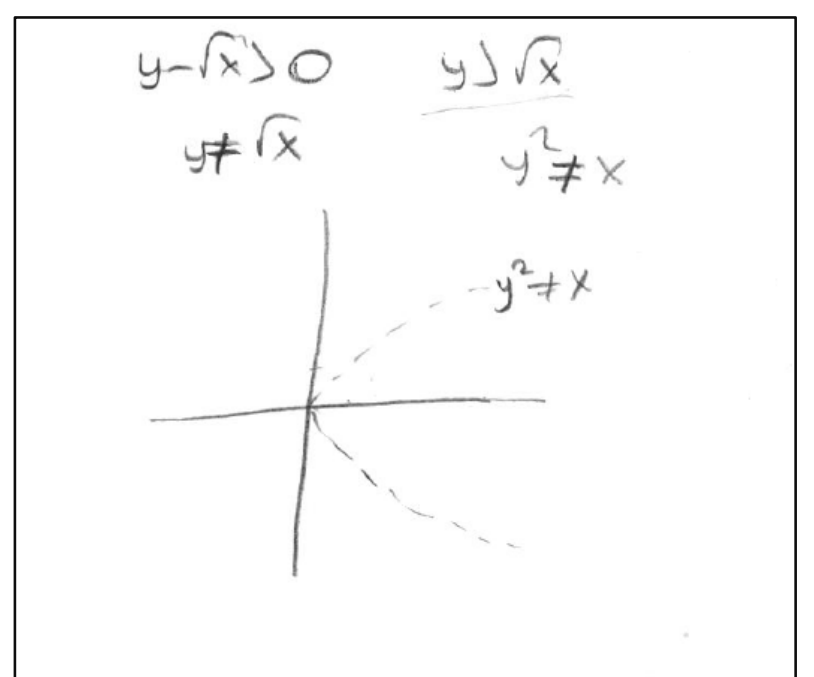

Figure 6. An example student answer included in the "Image Having" stage

\subsection{Findings with regard to the Third Question}

The answers submitted by preservice teachers for the question "Find the domain of $f(x, y)=\arctan \frac{x}{y}$ and show this on the coordinate plane" were evaluated according to the Pirie-Kieren model and the results below were obtained.

Table 3. Pirie-Kieren Understanding Levels for the Third Question

\begin{tabular}{ccccc}
\hline & $\begin{array}{c}\text { Image } \\
\text { making }\end{array}$ & $\begin{array}{c}\text { Image } \\
\text { Having }\end{array}$ & $\begin{array}{c}\text { Property } \\
\text { Noticing }\end{array}$ & Empty \\
\hline $\begin{array}{c}\mathbf{3}^{\text {rd }} \\
\text { Question }\end{array}$ & 7 & 18 & 12 & 3 \\
\hline
\end{tabular}



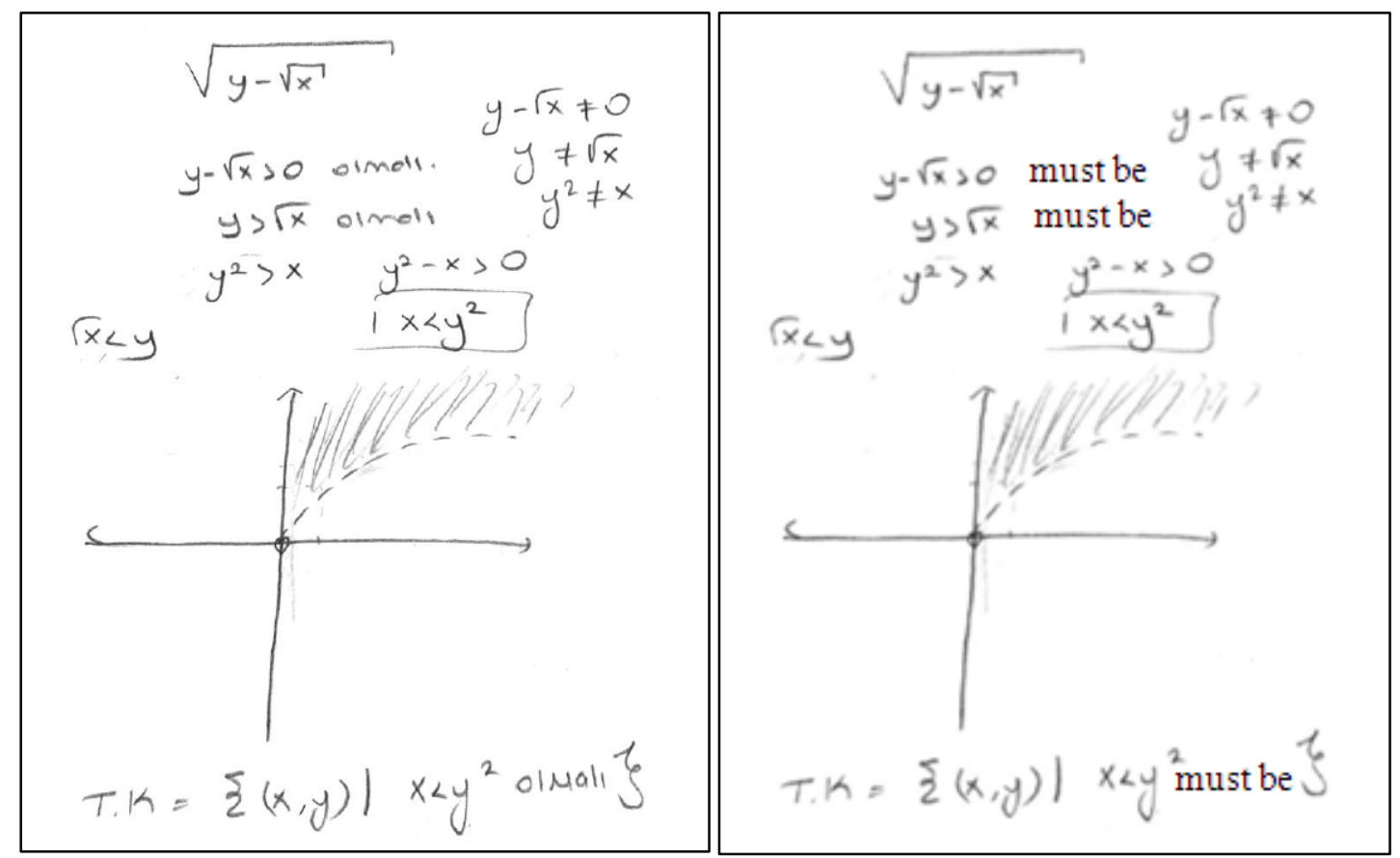

Figure 7. An example student answer included in the "Property Noticing" stage

For the third question, from the 40 answers submitted by students, 18 were included in the "Image Having" stage, 12 were included in the "Property Noticing" stage and 7 in the Image Making Stage. The situation regarding the breakdown of the answers is shown on the bar chart below.

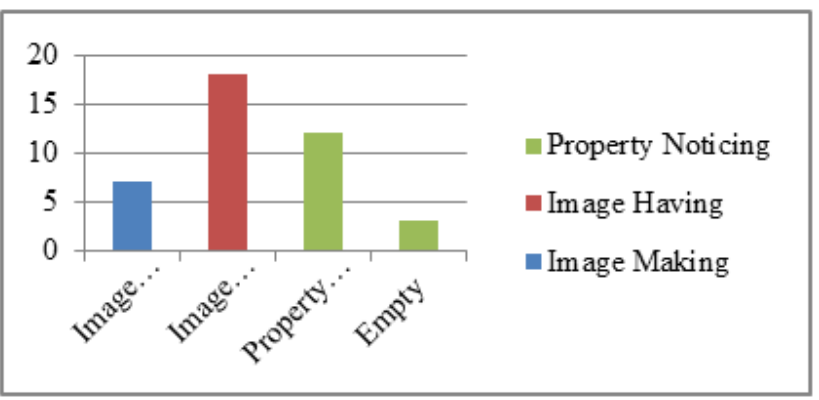

Figure 8. Bar chart for the third question

An example answer submitted by the students to the third question that was included in the "Image Making" stage is shown below:

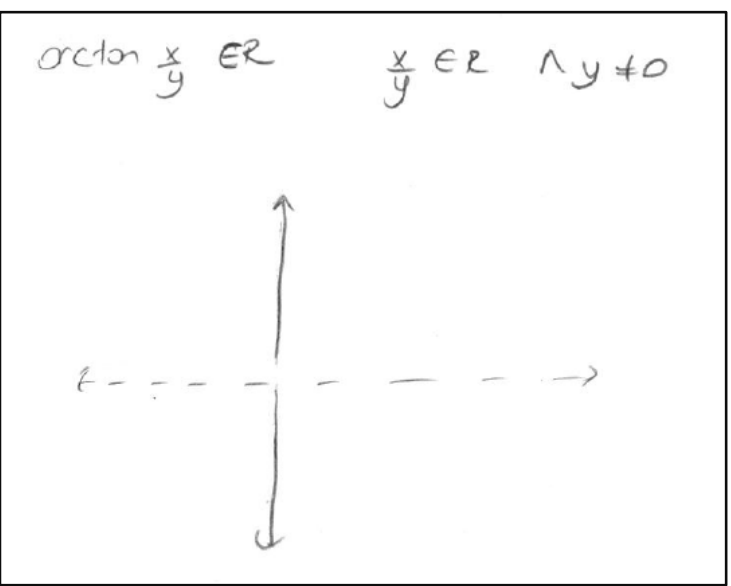

Figure 9. An example student answer included in the "Image Making" stage

Example answers of students whose answers were included in the stages: "Image Making" and "Property Noticing" for the third question: 

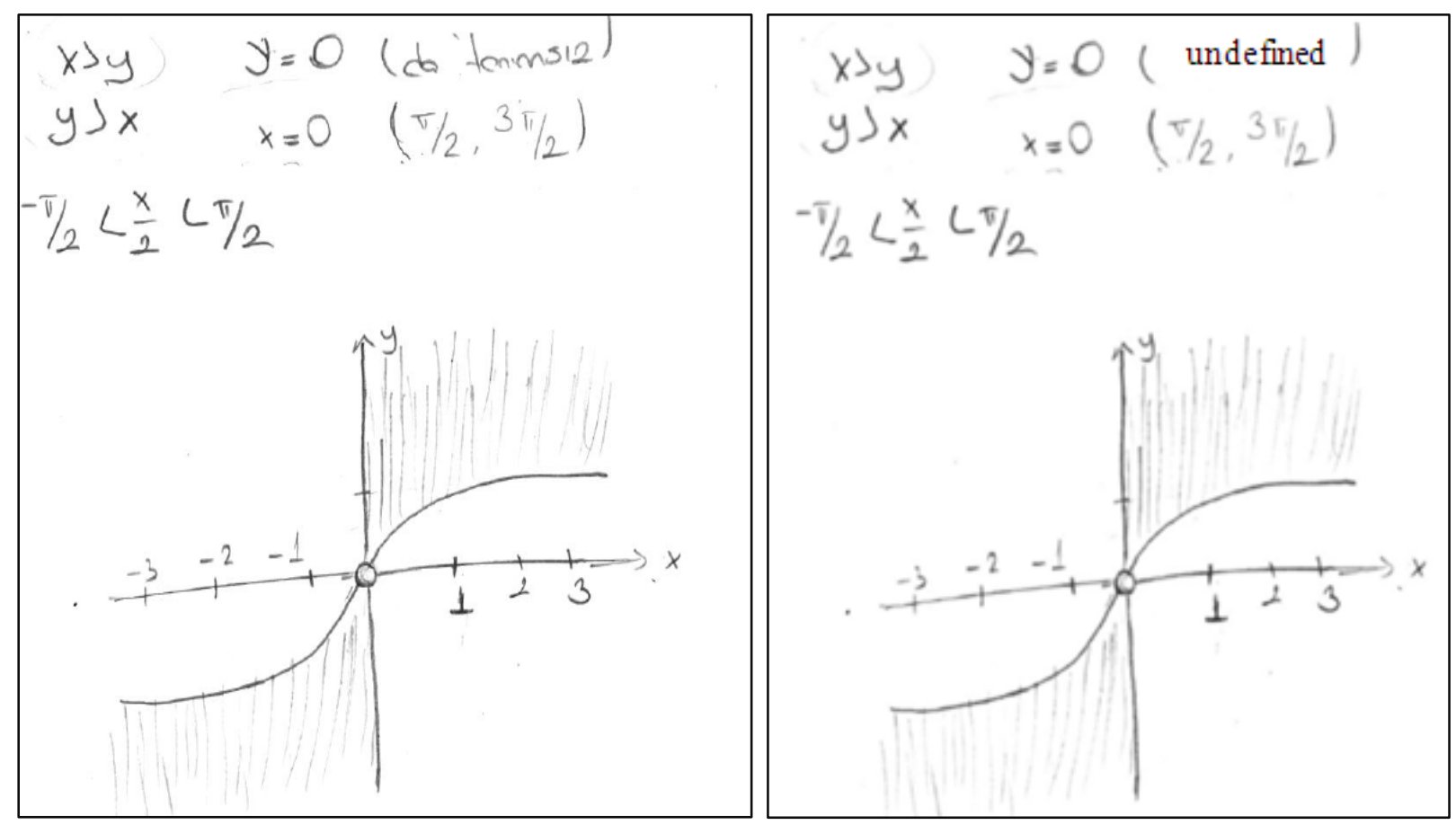

Figure 10. An example student answer included in the "Image Having" stage

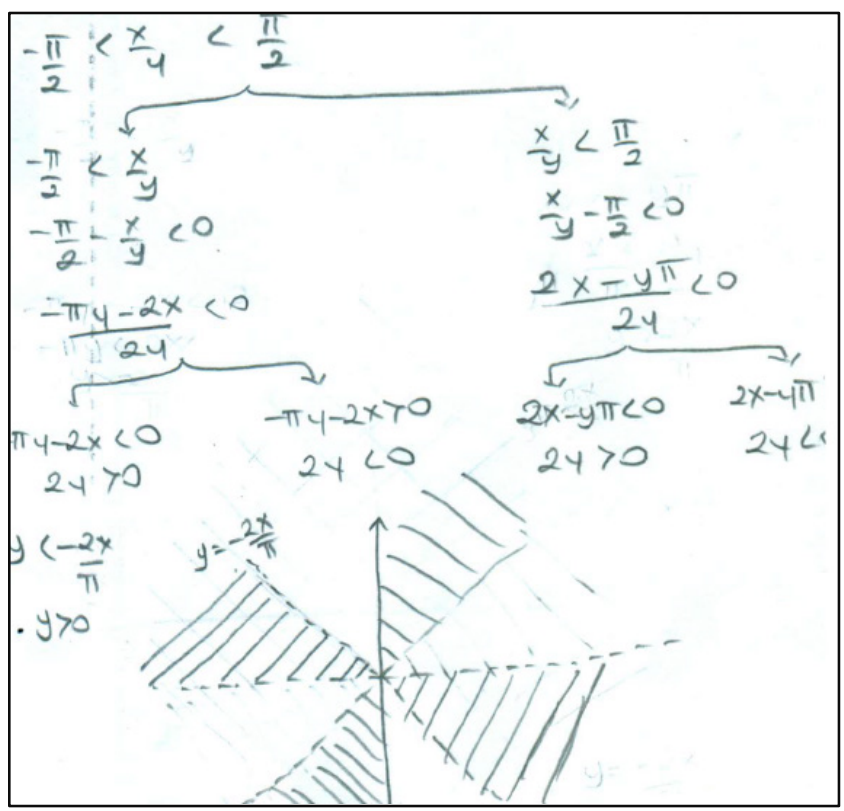

Figure 11. An example student answer included in the "Property Noticing" stage

\subsection{Findings with regard to the Fourth Question}

The answers submitted by primary school mathematics preservice teachers to the question: "Find the domain of $f(\mathrm{x}, \mathrm{y}, \mathrm{z})=\ln \left(4-\mathrm{x}^{2}-\mathrm{y}^{2}-\mathrm{z}^{2}\right)$ and show this on the coordinate plane" were evaluated according to the Pirie-Kieren model and the findings presented below were obtained:
Table 4. Pirie-Kieren Understanding Levels for the Fourth Question

\begin{tabular}{cccc}
\hline & $\begin{array}{c}\text { Image } \\
\text { Making }\end{array}$ & $\begin{array}{c}\text { Image } \\
\text { Having }\end{array}$ & $\begin{array}{c}\text { Property } \\
\text { Noticing. }\end{array}$ \\
\hline $\begin{array}{c}4^{\text {th }} \\
\text { Question }\end{array}$ & - & 5 & 35 \\
\hline
\end{tabular}

From the 40 answers submitted by students to the fourth question, 35 were included in the "Property Noticing" stage, while 5 were included in the "Image Having" stage. The situation as regards the breakdown of the answers submitted is shown on the bar chart below.

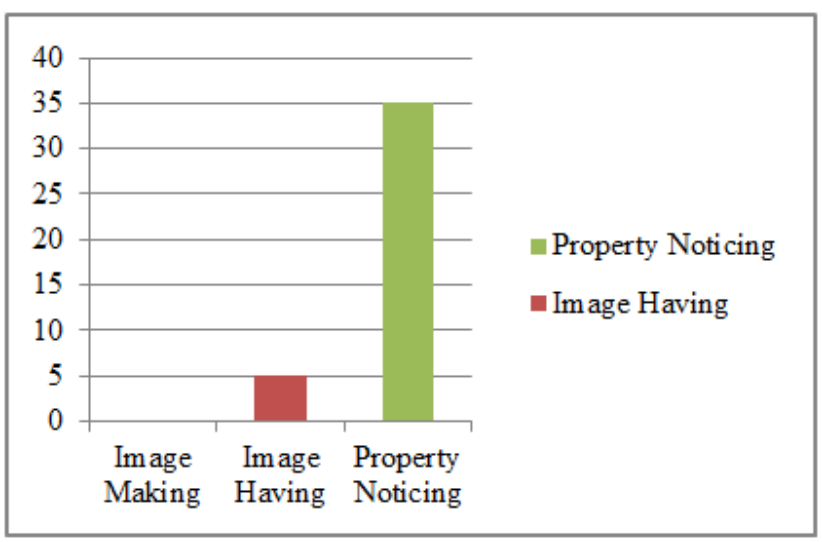

Figure 12. Bar chart for the third question

Examples of student answers to the fourth question that were included within the "Image Having" and "Property Noticing" stages are presented below: 

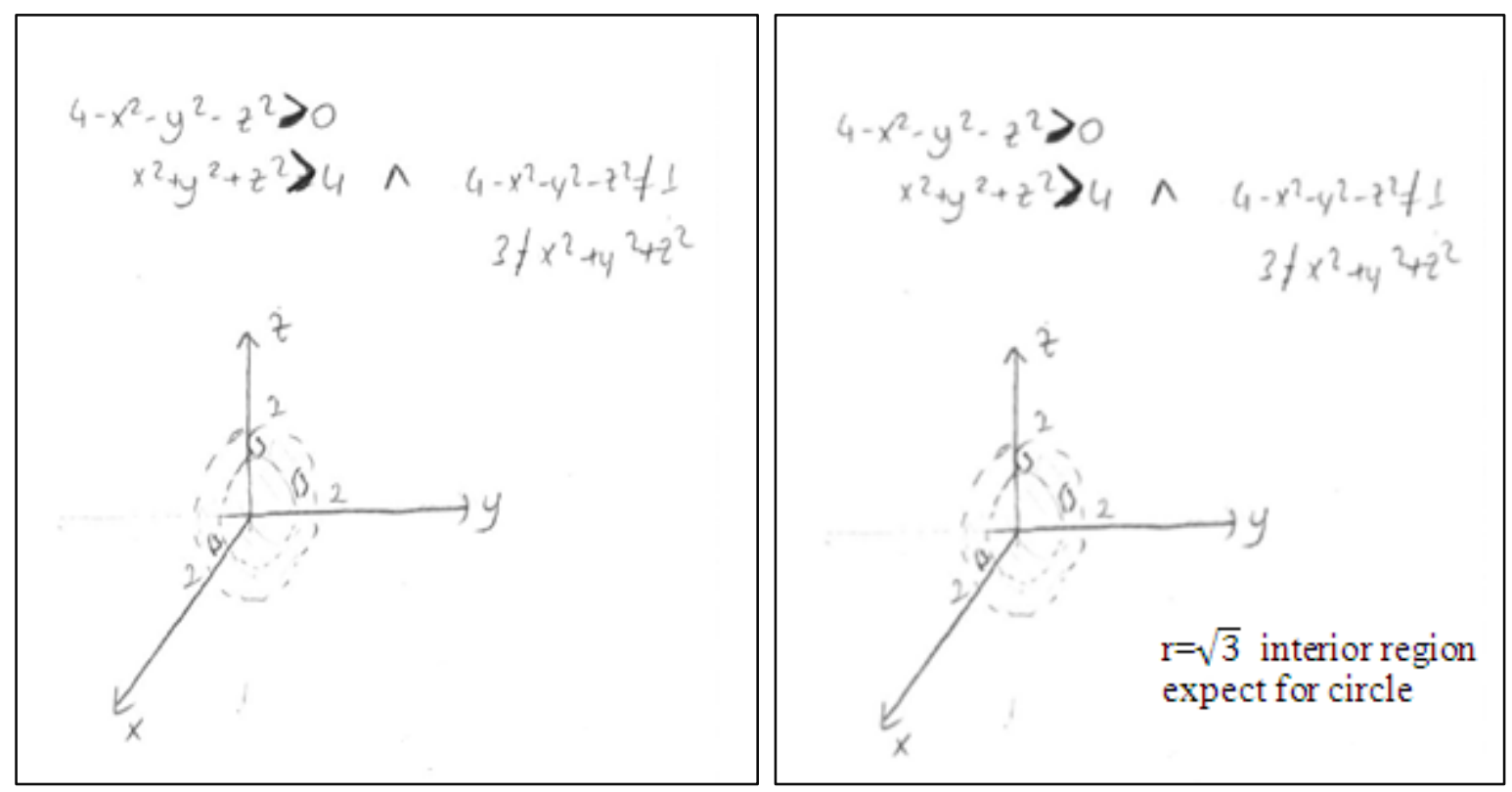

Figure 13. An example student answer included in the "Image Having" stage

The mathematical understandings of four preservice teachers selected after examination of their answers submitted for four questions are given below as examples in keeping with the constructs presented in the Pirie-Kieren model.
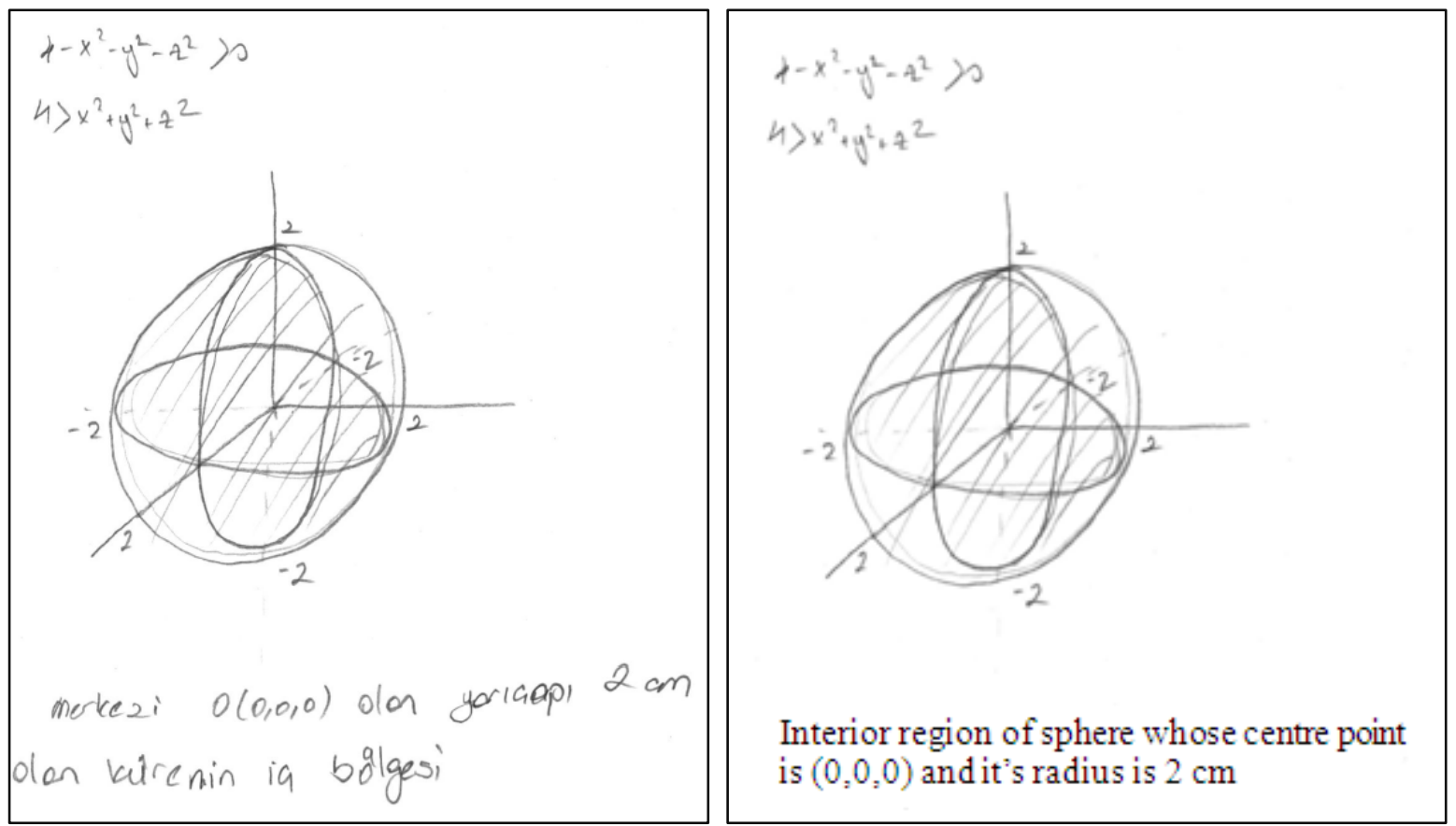

Figure 14. An example student answer included in the "Property Noticing" stage 


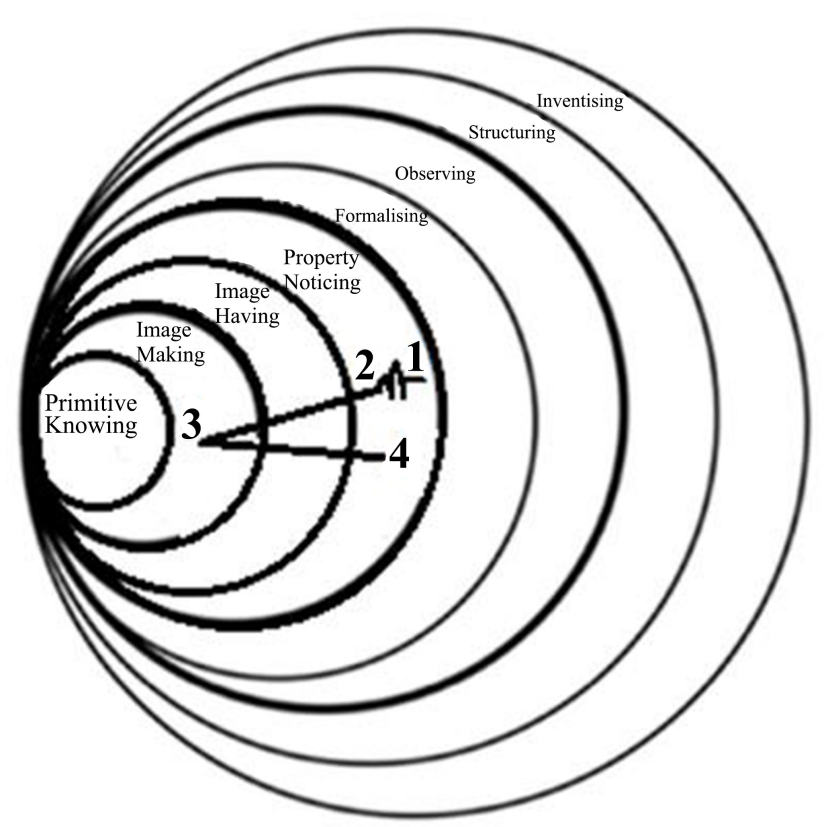

Figure 15. S1's mathematical understanding scheme

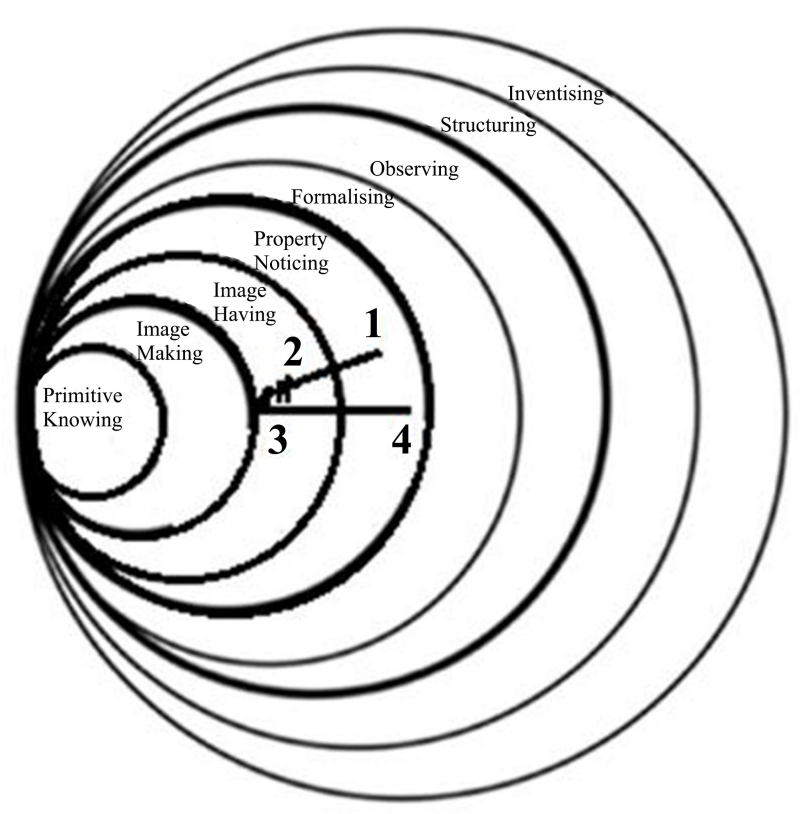

Figure 16. S2's mathematical understanding scheme

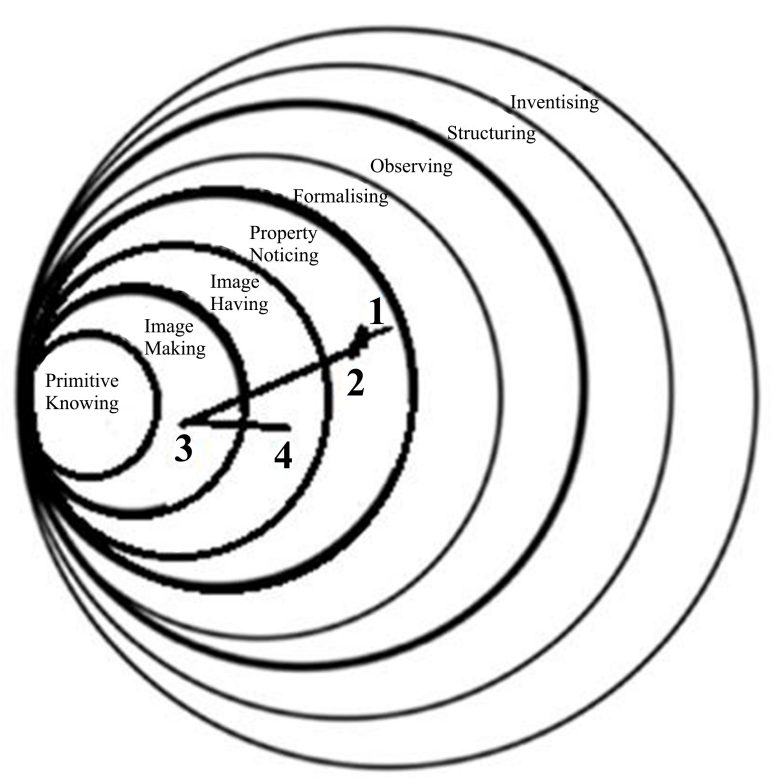

Figure 17. S3's mathematical understanding scheme

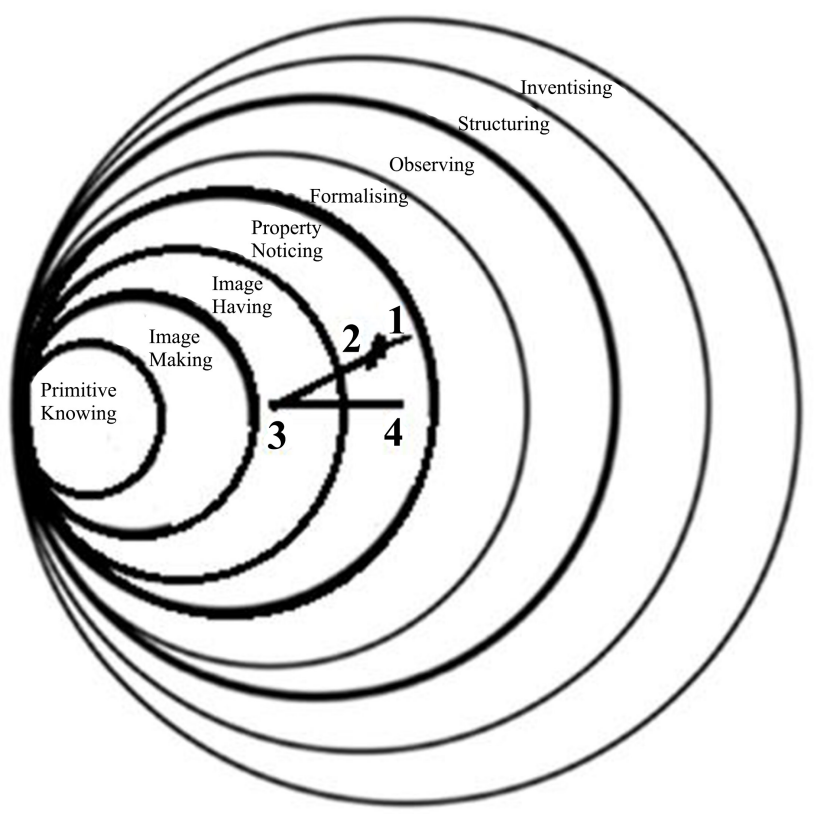

Figure 18. S4's mathematical understanding scheme 


\section{Discussion}

In the present study, the growth of mathematical understanding of primary mathematics preservice teachers regarding the concept of the domain of multivariable functions was described. Depending on the preservice teachers' preconceptions or learning outputs during the Analysis II courses, they gave different answers for questions. Preservice teachers responses moved between three layers of understanding (image making, image having, property noticing) for all questions. In addition, preservice teachers didn't reach the final layer of Pirie-Kieren model. Thus, answers appropriate for each Pirie-Kieren characteristics were not observed. Similar findings that were not obtained all levels of Pirie-Kieren model were found in some studies (e.g., [15], [25]).

The data for every question were evaluated separately. There was a multivariable function in the first question on the achievement test. The expression included both a quadratic square root as well as a trigonometric function. From 40 students, 37 participants, that is $92 \%$ were at the "Property Noticing" stage. In other words, they held images that were related both to square root and trigonometric functions. By thinking of both of these concepts at the same time they were able to define a common domain set. For this reason they were able to bring these images together and use them so as to solve the problem [6]. The remaining students held separate images concerning functions but were unable to combine these.

The function in the second question was a rational expression and again constituted a function with two variables. It should be noticed here that the denominator should be different from zero. In the expression of the denominator, there are two interrelated square root functions. In the internal square root only $x$ is present. The $x$ variables should be greater than or equal to zero. At the same time, the expression $\sqrt{y-\sqrt{x}}$ should be greater than zero but not be equal to zero. By drawing the related $y^{2}=x$ function, the domain set is defined on the coordinate plane. From 40 students, 32 participants or approximately $80 \%$ according to the Pirie-Kieren model were at the "property noticing" stage. It followed that by considering the square root expressions of the denominator, they had made a correct evaluation. They held the image that the interior of second degree square root expressions must be positive; however they considered these concepts separately and in general did not make a correct evaluation.

The answers submitted to the first and second questions correlated with the image having and property noticing stages according to the Pirie-Kieren model. However, on the third question, answers were also encountered that were included on the "image making" stage. Seven of the preservice teachers gave answers that were included in the "image making" stage. It followed that they were at a stage at which they were able to acquire an idea regarding what the question was concerned with the question [7]. The third question contains an inverse trigonometric function and contains a rational expression within a function. Two variables are contained within a rational expression. This was the question from the four with which students experienced the greatest difficulties.

3 preservice teachers left the question blank. In a departure from the first two questions, answers were given that were included in the "image having" stage. From this result, we can deduce that students at this level of understanding may create a mental construct so as to solve the problem without having to carry out specific activities [7]. From 40 students, the number of students that were able to perform this task was approximately 18 from 40 , or $45 \%$ of the participants. It may also be stated that students experienced difficulties in expressing the domain of an inverse tangent expression. In general, they did not have images with regard to this section or had incorrect knowledge of the topic. However, they were able to see easily that in a rational expression $x$ is greater than 0 . Two correct expressions emanating from the starting point have to be determined regarding the definition of the space needed to find $x / y$. and this then needs to be shown on the coordinate plane. 12 students were only able to conduct an evaluation in this way, and this corresponds to $30 \%$ of the total of participants.

While the first three questions included functions with dual variables, the fourth question included three variables. So as to show the domain of the function on the coordinate plane, three axes must be used. The function in the question is a logarithmic function. It follows that the expression within the function needs to be greater than zero $\left(4-x^{2}-\right.$ $\left.y^{2}-z^{2}\right)>0$. The equation $x^{2}+y^{2}+z^{2}=4$ indicates a sphere with a centre $(0,0,0)$ and radius of it is $2 \mathrm{br}$. In cases of inequality, the interior region of this sphere constitutes the domain set of the function. The answers were included within the "Image Having" and "Property Noticing" stages of the Pirie-Kieren model. 35 of the preservice teachers were at the "property noticing" stage. In other words, they defined that the expression containing three variables within a logarithmic function expressed a sphere and showed this on the coordinate plane. The remaining five students were either not able to think that this function expressed a sphere or made incorrect evaluations but nevertheless held images that allowed them to define the domain set of a function with three variables.

Because of the limits of this paper, it was presented only students' responses related to the concept of domain of multivariable functions. Embarking from the results of the answers submitted by preservice teachers to the questions in this study, the following may be suggested to researchers and applicants of education.

This study that took as its study group second-class students from the primary mathematics teaching department, who had completed the Analysis II course, may be conducted for other disciplines and lessons. Moreover, an experimental study may also be conducted.

In studies to be carried out involving preservice teachers or students, a comparison may be made between the Pirie-Kieren and APOS theories of education.

A pre-test may be carried out to ascertain the levels of 
previous knowledge of students and to what extent this knowledge is accurate.

By predicting difficulties and misconceptions that may be faced during teaching, an appropriate teaching program may be designed for incorporation within the curricula of faculties of education.

There were four tasks in this study. If the number of the tasks is increased, it will allow us to demonstrate the different levels of understanding about the domain of multivariable sets for future studies.

The preservice teachers' process of construction of the domain of multivariable sets was described only through their written responses. As a continuation of this study, adding observations of students about the state of the course work can be done with more qualitative data.

\section{REFERENCES}

[1] Skemp, R. R. (1987). The Psychology of Learning mathematics (Expanded American Ed.). Hillsdale, NJ: Lawrence Erlbaum Associates.

[2] Skemp, R. R. (1979). Goals of learning and qualities of understanding. Mathematics Teaching, Vol. 88, 44-49.

[3] Argat, A. (2012). Pirie-Kieren dinamik modeli ile öğrencilerde matematiksel anlamanın gelişiminin incelenmesi. Yayınlanmamıs yüksek lisans tezi. Marmara Üniversitesi Eğitim Bilimleri Enstitüsü, İstanbul.

[4] Meel, E. D. (2003). Models and theories of mathematical understanding: comparing Pirie and Kieren's Model of the growth mathematical understanding and Apos Theory. Journal of Mathematical Education, Vol. 12, 132-174.

[5] Von Glasersfeld, E. (1987). Learning as a constructive activity. In Problems of representation in the teaching and learning of mathematics. C. Janvier (Ed.). pp. 3-17. Hillsdale, NJ: Lawrence Erlbaum Associates.

[6] Pirie, S., \& Kieren, T. (1994). Growth in mathematical understanding: How can we characterise it and how can we represent it? Educational Studies in Mathematics, Vol. 26, No.2, 165-190.

[7] Lyndon, C. M. (2008). Folding back and the dynamical growth of mathematical understanding: Elaborating the pirie-kieren theory. Journal of Mathematical Behavior, Vol. 27, 64-85.

[8] Borgen, K. L. (2006). From mathematics learner to mathematics teacher: Preservice teachers' growth of understanding of teaching and learning mathematics (Doctoral dissertation). Retrieved from ProQuest Dissertations \& Theses Global. (UMI No: 304901557)

[9] Thom, J. S., \& Pirie, S. E. (2006). Looking at the complexity of two young children's understanding of number. The Journal of Mathematical Behavior, Vol. 25, No.3, 185-195.

[10] Balc1, M. (1999). Analiz. Ankara: Balcı yayınları.

[11] Biber, A. Ç., \& Argün, Z. (2012). Matematik öğretmen adaylarında iki değişkenli fonksiyonların limiti kavramının yapılandırılmasının incelenmesi. Mersin Üniversitesi Eğitim Fakültesi Dergisi, Vol. 8, No. 2, 56-66.

[12] Glanfield, F. (2004). Mathematics teacher understanding as an emergent phenomenon. In M. J. Hoines \& A. B. Fuglestad (Eds.), Proceedings of the twenty eighth annual meeting of the International Group for the Psychology of Mathematics Education, Vol. 1. (p.304).

[13] Cavey, L. O., \& Berenson, S. B. (2005). Learning to teach high school mathematics: Patterns of growth in understanding right triangle trigonometry during lesson plan study. Journal of Mathematical Behavior, Vol. 24, 171-190.

[14] McDougall, M., \& Nason, R. (2005). Growth of teacher knowledge within an on-line collaborative learning environment. In P. Clarkson, A. Downton, D. Gronn, M. Horne, A. McDonough, \& R. Pierce, et al. (Eds.), Proceedings of the Annual Conference of the Mathematics Education Research Group of Australasia (pp. 529-536).

[15] Gülkılık, H., Uğurlu, H. H., \& Yürük, N. (2015). Examining Students' Mathematical Understanding of Geometric Transformations Using the Pirie-Kieren Model. Educational Sciences: Theory \& Practice, Vol. 15, No. 6, 1531-1548.

[16] Kaba, Y., \& Sengül, S. (2015). Relationship between Middle School Students' Mathematical Understanding and Mathematical Attitude. Education and Science, Vol. 40, No. 180, 103-123.

[17] Akkoç, H. (2006). Fonksiyon kavramanın çoklu temsillerinin çağrıştırdığı kavram görüntüleri. Hacettepe Üniversitesi Eğitim Fakültesi Dergisi, Vol. 30, 1-10.

[18] Aydın, M., \& Köğce, D. (2008). Öğretmen adaylarının denklem ve fonksiyon kavramlarına ilişkin algıları, Yüzüncü Y1l Üniversitesi Eğitim Fakültesi Dergisi, Vol. 5, No. 1, 46-58.

[19] Karataş, I., \& Güven, B. (2004). Fonksiyon kavramının farklı öğrenim düzeyinde olan öğrencilerdeki gelişimi. Eurasian Journal of Educational Research (EJER), Vol. 16, 64-73.

[20] Ural, A. (2012). Fonksiyon Kavramı: Tanımsal Bilginin Kavramın Çoklu Temsillerine Transfer Edilebilmesi ve Bazı Kavram Yanılgıları. Pamukkale Üniversitesi Eğitim Fakültesi Dergisi, Vol. 31, 93-105.

[21] Biber, A. Ç., \& Argün, Z. (2015). Matematik Öğretmen Adaylarının Tek ve İki Değişkenli Fonksiyonlarda Limit Konusunda Sahip Oldukları Kavram Bilgileri Arasındaki İlişkilerin İncelenmesi Bartın Üniversitesi Eğitim Fakültesi Dergisi, Vol. 4, No. 2, 501-515.

[22] Dündar, S. (2015). Knowledge of mathematics teacher-candidates about the concept of slope/Matematik öğretmeni adaylarının eğim kavramına ilişkin bilgileri. Eğitimde Kuram ve Uygulama, Vol. 11, No. 2, 673-693.

[23] Kaya, D., \& Aydin, H. (2014). Elementary Mathematics Teachers' Perceptions and Lived Experiences on Mathematical Communication. Eurasia Journal of Mathematics, Science \& Technology Education, Vol. 10, No. 6, 619-629.

[24] Iymen, E., \& Paksu, A. D. (2015). Analysis of 8th Grade Students' Number Sense Related to the Exponents in Terms of 
Number Sense Components. Education and Science, Vol. 40, No. 177, 109-125.

[25] Codes, M., González Astudillo, M. T., Delgado Martín, M. L., \& Monterrubio Pérez, M. C. (2013). Growth in the understanding of infinite numerical series: a glance through the Pirie and Kieren theory. International Journal of Mathematical Education in Science and Technology, Vol. 44, No. 5, 652-662. 